\title{
IV ŚWIATOWE SPOTKANIE RODZIN: „RODZINA CHRZEŚCIJAŃSKA - DOBRA NOWINA NA TRZECIE TYSIĄCLECIE” MANILA (FILIPINY), 22-26 STYCZNIA 2003 ROKU
}

W dzisiejszym świecie wielu zdaje się zapominać, że instytucja małżeństwa i rodziny ma Boży charakter i strukturę. Że winna być szkołą wiary, miłości i modlitwy. Dowodem na to mogą być podejmowane w wielu krajach próby zrównywania rodziny i związków homoseksualnych do jednego mianownika. Jan Paweł II w jasny sposób daje do zrozumienia, że żaden rząd nie może manipulować tą podstawową komórką społeczną i ingerować w jej naturę.

Okazją do przypomnienia tych, jak też innych fundamentalnych zasad są organizowane od 1994 roku Światowe Spotkania Rodzin. Serię tego rodzaju inicjatyw duszpasterskich rozpoczął Ojciec Święty Jan Paweł II w Roku Rodziny. Spotkania takie odbywają się co trzy lata. Pierwsze odbyło się w 1994 roku w Rzymie. Kolejnym miejscem było Rio de Janeiro (1997) i ponownie Rzym podczas trwającego Roku Jubileuszowego.

W Manili, stolicy Filipin w dniach 22-26 stycznia b.r. odbyło się IV Światowe Spotkanie Rodzin pod hasłem: Rodzina chrześcijańska - dobra nowina na trzecie tysiqclecie.

Filipiny to azjatycki kraj złożony z ponad 7100 wysp. To jedyny kraj tego kontynentu, gdzie rozwinął się katolicyzm. Filipiny nazywane są azjatyckim przedmurzem chrześcijaństwa. Nie bez powodu. Z chrześcijaństwa bowiem wypływa tu prawo stanowione. Konstytucja filipińska broni życia od poczęcia i zakazuje rozwodów. Ten właśnie kraj wybrał Ojciec święty na miejsce kolejnego Spotkania Światowego Rodzin.

Spotkanie w Manili rozpoczął Międzynarodowy Kongres Teologiczny. Podczas jego inauguracji nuncjusz apostolski na Filipinach abp Antonio Franco przekazał pozdrowienia dla uczestników od Jana Pawła II. W trzydniowym Kongresie nawiązującym do hasła przewodniego uczestniczyło 3,7 tysiąca delegatów $\mathrm{z}$ siedemdziesięciu dwóch państw świata. W specjalnym przesłaniu odczytanym przez abpa Franco Ojciec Święty wyraził swój żal z powodu 
swojej nieobecności w Manili. Papież zapewnił, że bardzo chciał przybyć na święto rodzin na Filipinach, ale okazało się to niemożliwe. „Będziemy towarzyszyć wam naszymi modlitwami” - zapewnił Ojciec Święty. W tym samym przesłaniu papież mianował swoim nadzwyczajnym wysłannikiem kardynała Alfonso Lopez Trujillo, przewodniczącego Papieskiej Rady ds. Rodziny.

Zgromadzonych w głównej auli Filipińskiego Centrum Kongresowego powitał przewodniczący Komitetu Organizacyjnego uroczystości bp Socrates Villegas. „Jesteśmy biednym krajem i młodą demokracją, ale jesteśmy bogaci naszą wiarą i naszą miłością do rodziny" - powiedział bp Villegas.

Burzliwe oklaski powitały kolejnego mówcę, arcybiskupa Manili kard. Jaime Sina. „Dumny jestem, że Filipiny w ogóle i Manila w szczególności zostały wybrane raz jeszcze przez Ojca Świętego na tak ważne wydarzenie w życiu Kościoła" - powitał zgromadzonych kardynał, który cieszy się tutaj niezwykłym autorytetem. Był on jednym z głównych promotorów bezkrwawej rewolucji na Filipinach w 1986 roku, kiedy dwa miliony ludzi z różańcami w rękach obaliło dyktaturę Ferdinanda Marcosa.

Kard. Sin pozdrowił także najmłodszych uczestników kongresu. Jako oficjalnych uczestników konferencji zarejestrowano bowiem czterdzieści dwa niemowlęta. „Nie wiem czy zrozumieją cokolwiek z naszych obrad - zażartował Sin - ale cieszę się, że są z nami całe rodziny".

Mszę św. otwierającą Kongres odprawił przewodniczący Konferencji Biskupów Filipin, abp Orlando Quevedo. W koncelebrze uczestniczył metropolita krakowski, kardynał Franciszek Macharski, który w czasie kongresu wygłosi referat „O rodzinie jako drodze Kościoła”. Kard. Macharski powiedział KAI, że jest to rozwinięcie tematu o człowieku nazwanym przez papieża Jana Pawła II „drogą Kościoła”. - To pierwszy powód mojej obecności tutaj - wyjaśnił metropolita krakowski. - „Drugim jest fakt - stwierdził polski kardynał - że na Filipinach najbardziej w całej Azji rozwinęło się nabożeństwo do Miłosierdzia Bożego".

Polskę w Manili reprezentowała dwudziestoosobowa delegacja z wspomnianym już metropolitą krakowskim kardynałem Franciszkiem Macharskim i przewodniczącym Rady Episkopatu Polski ds. Rodziny, biskupem łomżyńskim Stanisławem Stefankiem na czele. Obecność Polski na kongresie została także zaznaczona na różne sposoby, na przykład: w grupie małżeństw, które ze świecami w rękach szły ma czele procesji podczas Mszy św. inauguracyjnej znalazły się dwie polskie pary: Ewa i Lech Kowalewscy z Human Life International Europa oraz Paweł i Mirosława Kwasowie z Rady Episkopatu Polski ds. Rodziny.

W wielu wykładach (teksty wykładów dostępne są w języku angielskim w materiałach wydanych drukiem jako akty kongresowe) przypominano praw- 
dę, że rodzina to nie tylko instytucja społeczna, ale przede wszystkim sakrament. Na tym polega wielkość małżeństwa chrześcijańskiego, że jest to przymierze zawierane między sobą, ale wobec samego Jezusa Chrystusa, który jest jego świadkiem. Dlatego małżeństwo chrześcijańskie jest wołaniem w stronę przyszłości, ażeby na tym mocnym fundamencie budować przyszłość świata. Wszystkie małżeństwa na świecie zagrożone są współczesnymi przejawami działania zła, takimi jak aborcja, postulowanie „małżeństw” homoseksualnych i eutanazja. Apele, których słuchaliśmy, były wielkim wołaniem o życie i dla życia.

Wyrazem troski o życie były występy dzieci, a także czynny udział licznych małżeństw w Liturgii. Małżonkowie czytali teksty mszalne, odmawiali modlitwę wiernych, szli w procesji z darami... Ukazuje to, że powołanie do życia w rodzinie ma równie wielką wartość dla Kościoła, jak stan kapłański czy zakonny.

Treść wystąpień kongresowych da się sprowadzić do kilku słów kluczy. Pierwszym słowem dobrej nowiny jest PRAWDA. Rodzina - czym jest i czym powinna być według zamysłu Bożego? To jest ten wspaniały skarbiec, który każda rodzina niesie jako Kościół domowy. Każda rodzina jest właścicielem tego skarbca, jest właścicielem prawdy i dlatego może być światłem, może być przewodnikiem. A prawda pochodzi od Boga, bo On jest stwórcą rodziny. Bóg Stwórca zaprogramował szczegółowe relacje między małżonkami: mężem i żoną, oraz między rodzicami i dziećmi.

Prawda w sposób szczególny opisuje drugie słowo, a jest nim MIŁOŚĆ. Najdłużej trzeba zatrzymać się przy miłości, która została pozbawiona treści, a której trzeba przywrócić jej dynamikę i skuteczność. Miłość jest „łaską, którą otrzymaliście w sakramencie małżeństwa i która trwa w czasie, pochodzi z przebitego włócznią Serca Odkupiciela, który na ołtarzu Krzyża złożył się w ofierze za Kościół, swą oblubienicę, idąc na śmierć, aby zbawić wszystkich. Ta łaska zatem niesie ze sobą specyfikę związaną z jej pochodzeniem: jest łaską miłości, która się ofiaruje, miłości, która oddaje się i przebacza; miłości bezinteresownej, która zapomina o własnym cierpieniu; miłości wiernej aż do śmierci; miłości owocującej życiem".

Miłość ofiarna otwiera przed rodziną drogę ŚWIĘTOŚCI. „Oczywiście nie zawsze jest to łatwe i w życiu codziennym nie brak zasadzek, napięć, cierpienia i także zmęczenia. Jednak na swojej drodze nie jesteście sami. Z wami jest zawsze obecny i działa Jezus - tak jak był w Kanie Galilejskiej, w chwili trudności dla tamtych nowożeńców" - mówił Ojciec Święty do rodzin świata.

Życie w żywym sakramentalnym zjednoczeniu z Jezusem owocuje SZCZĘŚCIEM w rodzinie i otwiera dom własnej rodziny na głoszenie Dobrej Nowiny innym wspólnotom. Rodzina podejmuje zadania MISJI - bądźcie przewodni- 
kami w Kościele i w świecie: to konieczność, która wypływa z samego sakramentu małżeństwa, który zawarliście, z waszego bycia Kościołem domowym, z waszej misji małżeńskiej, która charakteryzuje was jako podstawowe komórki społeczeństwa.

Kongresowi teologicznemu towarzyszył Kongres Córek i Synów, w którym uczestniczą dzieci dorosłych delegatów. Bardzo głęboko przemówiło do zebranych odczytanie oświadczenia Kongresu Dzieci (Synów i Córek). Zostało to naprawdę wspaniale przygotowane: i dziewczynka wybrana do czytania, i sceny, które podczas czytania dokumentu były pokazywane na telebimie. Oto fragment tego oświadczenia: "Mówimy głośno, aby cały świat usłyszał: „Dziękujemy!” Dziękujemy Jezusowi, który sprawił, że te dni były tak radosne i tak owocne! (...) Wyznajemy naszą najgłębszą wiarę w Rodzinę Chrystusową jako Dobrą Nowinę na Trzecie Milenium: Wierzymy w Rodzinę Chrystusową, która odzwierciedla miłość Bożą. (...) Wierzymy w Rodzinę Chrystusową, która służy życiu. (...) Wierzymy w Rodzinę Chrystusową, która żyje i odzwierciedla radośnie swoje powołanie w obrębie Kościoła, w ten sposób stając się środkiem przekształcania świata w cywilizację miłości”.

IV Światowe Spotkanie Rodzin w Manili zakończyła Msza św. koncelebrowana dla kilkuset tysięcy pielgrzymów, którą odprawił specjalny wysłannik papieża, przewodniczący Papieskiej Rady Rodziny, kard. Alfonso Trujillo.

„Każde dziecko ma prawo do życia, do miłości, do nauki” - mówił papieski legat do wiernych zgromadzonych w Parku Luneta. Kard. Trujillo nazwał aborcję karą śmierci dla niewinnych i zwrócił się do rodzin świata z przejmującym apelem: „Nie zamieniajcie domów w groby, nikt nie może nienawidzić i zabijać człowieka, którego stworzył Bóg”. Pytał też zgromadzonych: „Czy wierzycie, że dziecko jest najcenniejszym podarunkiem?” „Wierzymy” - odpowiedział chór kilkuset tysięcy głosów.

Uroczysta Msza rozpoczęła się od wprowadzenia na ołtarz figurki Dzieciątka Jezus. Procesja poprzedzana orkiestrą przeszła kilkusetmetrową trasę okazując swą radość tańcem i muzyką. Nabożeństwo do Dzieciątka Jezus, którego sanktuarium znajduje się na wyspie Cebu jest najstarsze na Filipinach, a jego początki sięgają drugiej połowy szesnastego wieku. Jak głosi tradycja, figurka Dzieciątka należała do Ferdynanda Magellana, który podarował ją żonie wodza plemienia na wyspie Cebu. Figurka została odnaleziona przez Hiszpanów przybyłych na Filipiny po śmierci Magellana. Obecnie czczona jest w Bazylice Cebu. Intronizacja figurki była wymownym symbolem dla tutejszej ludności, ponieważ Filipińczycy w Dzieciątku Jezus widzą dostępnego dla wszystkich Boga, do którego można się zbliżyć bez strachu. W czasie Mszy przedstawiciele rodzin odnowili także swoje zobowiązania do życia na co dzień Ewangelią. 
Podczas IV Światowego Spotkania Rodzin poruszono wiele aspektów doktrynalnych i pastoralnych dotyczących małżeństwa i rodziny. Wiele także było wspaniałych przeżyć. Atmosfera spotkań była niezwykła. Byliśmy mile zaskoczeni zarówno przygotowaniem Liturgii ze wstawkami artystycznymi, które są typowe dla kultury filipińskiej, jak i doświadczeniem ich ogromnej gościnności.

Myślę jednak, że najważniejszym jest robić wszystko, aby rodzina pozostała sobą i była dobrą nowiną na początek trzeciego tysiąclecia. Następne, piąte Światowe Spotkanie Rodzin odbędzie się na kontynencie europejskim, gospodarzem uroczystości będzie Walencja w Hiszpanii.

ks. Adam Skreczko 